\title{
Appointing Women to Boards: Is There a Cultural Bias?
}

\section{Amalia Carrasco, Claude Francoeur, Réal Labelle, Joaquina Laffarga \& Emiliano Ruiz-Barbadillo}

\author{
Journal of Business Ethics \\ ISSN 0167-4544 \\ Volume 129 \\ Number 2 \\ J Bus Ethics (2015) 129:429-444 \\ DOI 10.1007/s10551-014-2166-Z
}

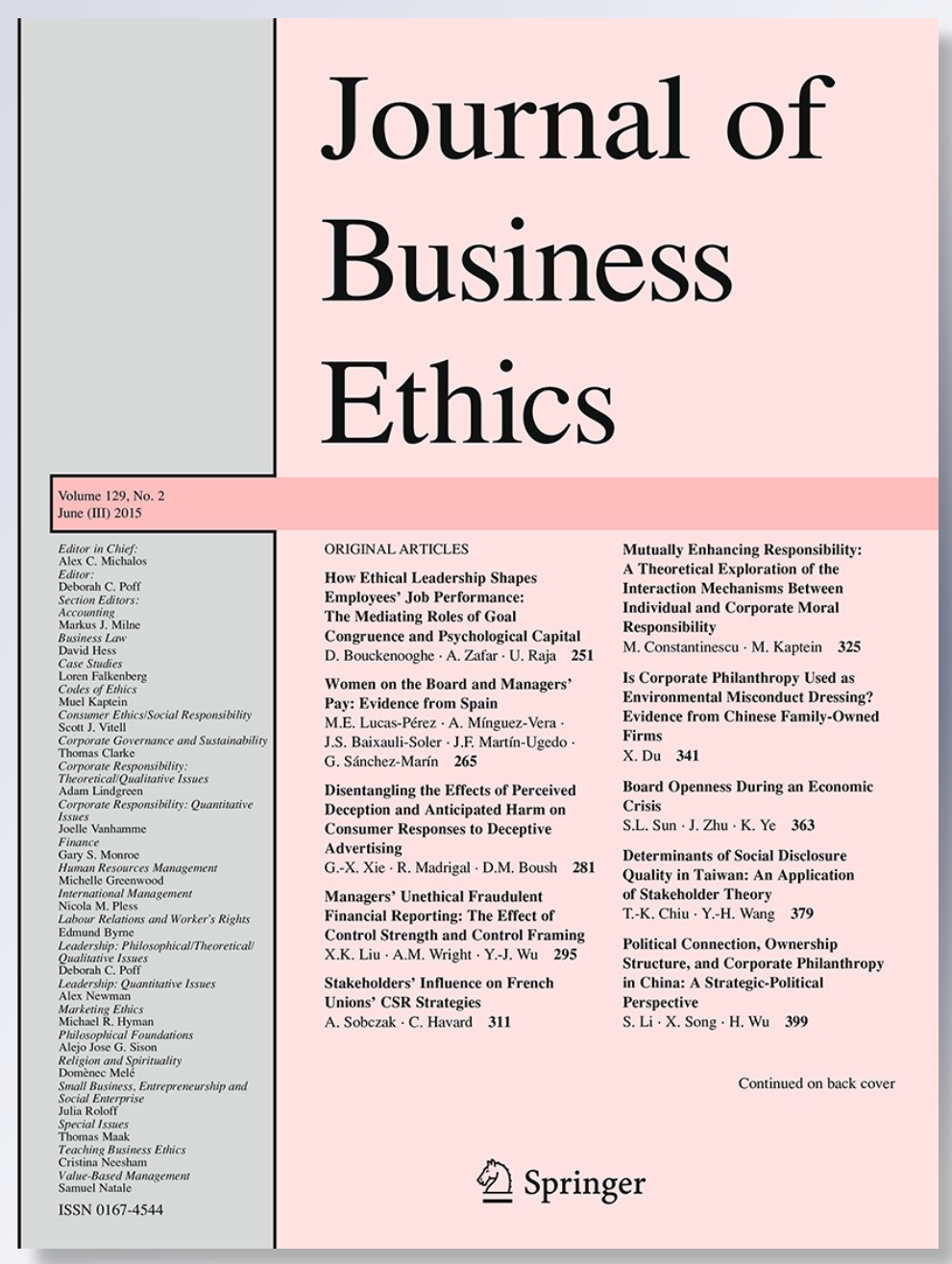

勧 Springer 
Your article is protected by copyright and all rights are held exclusively by Springer Science +Business Media Dordrecht. This e-offprint is for personal use only and shall not be selfarchived in electronic repositories. If you wish to self-archive your article, please use the accepted manuscript version for posting on your own website. You may further deposit the accepted manuscript version in any repository, provided it is only made publicly available 12 months after official publication or later and provided acknowledgement is given to the original source of publication and a link is inserted to the published article on Springer's website. The link must be accompanied by the following text: "The final publication is available at link.springer.com". 


\title{
Appointing Women to Boards: Is There a Cultural Bias?
}

\author{
Amalia Carrasco $\cdot$ Claude Francoeur • \\ Réal Labelle $\cdot$ Joaquina Laffarga • \\ Emiliano Ruiz-Barbadillo
}

Received: 18 May 2013/Accepted: 24 March 2014/Published online: 11 April 2014

(C) Springer Science+Business Media Dordrecht 2014

\begin{abstract}
Companies that are serious about corporate governance and business ethics are turning their attention to gender diversity at the most senior levels of business (Institute of Business Ethics, Business Ethics Briefing 21:1, 2011). Board gender diversity has been the subject of several studies carried out by international organizations such as Catalyst (Increasing gender diversity on boards: Current index of formal approaches, 2012), the World Economic Forum (Hausmann et al., The global gender gap report, 2010), and the European Board Diversity Analysis (Is it getting easier to find women on European boards? 2010). They all lead to reports confirming the overall relatively low proportion of women on boards and the slow pace at which more women are being appointed. Furthermore, the proportion of women on corporate boards varies much across countries. Based on institutional theory, this study hypothesizes and tests whether this variation can be
\end{abstract}

\footnotetext{
A. Carrasco $\cdot$ J. Laffarga

University of Sevilla, Sevilla, Spain

C. Francoeur $(\bowtie) \cdot$ R. Labelle

HEC Montréal, Montréal, QC, Canada

e-mail: claude.francoeur@hec.ca

E. Ruiz-Barbadillo

University of Cádiz, Cádiz, Spain
}

attributed to differences in cultural settings across countries. Our analysis of the representation of women on boards for 32 countries during 2010 reveals that two cultural characteristics are indeed associated with the observed differences. We use the cultural dimensions proposed by Hofstede (Culture's consequences: International differences in work-related values, 1980) to measure this construct. Results show that countries which have the greatest tolerance for inequalities in the distribution of power and those that tend to value the role of men generally exhibit lower representations of women on boards.

Keywords Culture $\cdot$ Board of directors $\cdot$ Gender $\cdot$ Gender diversity $\cdot$ Diversity $\cdot$ Cross-country $\cdot$ Corporate governance

\section{Introduction}

Board gender diversity is an important ethical issue for companies (Institute of Business Ethics 2011, p. 1) and is promoted in several countries' laws and national governance codes. There have been numerous national and international studies examining the factors influencing the composition of corporate boards of directors (e.g., Dalton et al. 1998) and the presence of women directors on boards (e.g., Terjesen et al. 2009). One strand of this research examines the presumed relationship between national culture and board structure (Hickson and Pugh 1995; House et al. 1999; Li and Harrison 2008; Semenov 2000). These studies focus on the level of independence of the directors. We wish to extend this line of research by focusing on whether cultural characteristics drive the appointment of women to corporate boards across countries. 
Catalyst (2011) ${ }^{1}$ published the following statistics on the proportion of women on boards by country: Sweden (27.3\%); Finland (24.5\%); Denmark (13.9\%); United Kingdom (15\%); Belgium (7.7\%); Spain (9.3\%), and Italy $(3.7 \%)$. Concerned about this under-representation of women and the slow rate of progress in this regard, several European Union countries are trying to bridge the gap between genders in corporate governance by imposing objectives or quotas for listed companies. For instance, in 2003 Norway adopted a law requiring that $40 \%$ of all publicly listed company board members be women by 2008, which explains why Norway has the highest rate of representation at $44.2 \%$ (Catalyst 2008). Spain, France, and Belgium have passed similar laws, with compliance deadlines in 2015 (Spain equality law 2007), 2017, and 2018 (Catalyst 2011), respectively. Germany and Sweden have adopted a comply or explain approach (Catalyst 2011). In Britain, the Financial Reporting Council (2011) is considering amending the UK Corporate Governance Code to require listed companies to establish a policy concerning boardroom diversity, including measurable implementation objectives, and to annually disclose a summary of the measures adopted and of the progress made in achieving the objectives (Davies 2011). Eventually, adoption of such rules or guidelines may considerably reduce the differences between countries. However, in the meantime, the crosscountry differences remain significant.

In light of the above statistics and reactions from governments, our research question is: Why does the level of female representation on corporate boards of directors differ so much from one country to another? More specifically, we wish to examine whether and to what extent the culture of a country may affect the level of female representation. Despite an extensive literature on the reasons why women should have better access to corporate boards and constitute a critical mass (Labelle et al. 2010; Haslam et al. 2010, Konrad et al. 2008; Kramer et al. 2006; Carter et al. 2003; Burgess and Tharenou 2002) and despite important differences in women's representation on boards of directors across countries, prior studies have not investigated the possible

\footnotetext{
${ }^{1}$ Several other prominent organizations confirm the imbalance of women on boards worldwide and the wide variation between countries. The Corporate Gender Gap Report of 2010, published by the World Economic Forum, presents the results of a survey of more than 3,400 companies including the 100 largest employers in each of the 30 member countries of the Organization for Economic Cooperation and Development (OECD), together with Brazil, Russia, and China. The 2010 European Board Diversity Analysis, prepared by Egon Zehnder International, analyzes data on 340 of the largest companies (market capitalization of more than EUR 4 billion) across 17 European countries. The report of Lord Davies of Abersosch, published on February 24, 2011 and commissioned by the United Kingdom government, examines the current situation of the FSTE 350 boards and gives its conclusion after wide consultation with various interested parties.
}

influence of national cultural dimensions on women's access to boards. Based on 6 case studies conducted in the contexts of four European countries (UK, Norway, Spain and the Netherlands), Sealy and Doldor (2009b) conclude that it is vital to consider the cultural and political context when examining board diversity.

Culture is defined as the set of values, beliefs, principles, and attitudes that are widely shared within a group of people (Hofstede 1980). Shared culture conditions individual behavior in the various spheres of everyday life and may thus help better understand these behaviors. It is on this basis that we use institutional theory to examine whether culture differently conditions the social roles assigned to men and women and even encourages gender stereotypes, which may influence firm's decisions to elect women to boards of directors.

Following the seminal work of Hofstede (1980), several studies have examined how corporate decision-making may be influenced by cultural dimensions (Gray, 1988; Salter and Niswander 1995; Ralston et al. 1993; Pedersen and Thomsen 1997; Semenov 2000; Stulz and Williamson 2003; Hope 2003; House et al. 2004; Guiso et al. 2006). We wish to contribute to this line of research by examining whether national cultural dimensions are associated with firms' decisions to appoint female directors.

We analyze the rate of representation of women on boards of directors of 7,302 publicly traded companies in 32 countries. Along with our variable of interest pertaining to the cultural dimensions of a country, we control for other factors likely to affect female board representation, such as board size, whether the Chair of the board is a woman, firm size, profitability and industrial sector, and the country's code of corporate governance. Our results show that two cultural characteristics, as measured by the Hofstede (1980) dimensions, are associated with variations observed in the level of female representation on corporate boards.

Our article is structured as follows. Cultural factors and the theoretical framework on which we base our study are set forth in "Theoretical Framework Linking Culture and Board Gender Diversity" section. We develop our hypotheses in "Hypotheses" section. "Methodology" section describes the methodology. The results of our descriptive, univariate, and multivariate analyses are presented and interpreted in "Results and Analyses" section, followed by a robustness analysis. Finally, "Conclusions" section presents a discussion of the results and conclusions.

\section{Theoretical Framework Linking Culture and Board Gender Diversity}

There is no agreement within social sciences on a definition of the concept of culture. In general, culture refers to a set 
of parameters that significantly differentiates one group from another. For Hofstede (1980), culture is considered as the collective social program that determines the set of values, beliefs, principles, and attitudes shared by members of a specific social community. House et al. (2004) suggest that culture serves as the reference frame that makes possible the interpretation and meaning of significant common events experienced by the members of a community; such experiences are very important and passed down through the generations. The fundamental characteristic of culture is that it is a social design that conditions the majority of social practices and processes. Therefore, a great deal of social behavior can be understood through the prevailing culture or social norms. With regard to the object of this study, the gender perspective in one country can be affected by culture, i.e., the mental structure through which individuals think about their social world, generating gender stereotypes or roles associated with women that could influence the presence of women on boards (Nelson and Levesque 2007).

The notion of gender is in itself a cultural construct created to refer to differences between men and women in society in terms of attitude, mental structures, and expectations. Gender as a notion goes beyond biological differences. Social beliefs about the roles of men and women surface in notions such as gender equality or discrimination. Some societies seem to ignore these differences when assigning roles; others seem to maximize them (House et al. 1999).

Several studies examine the different roles assigned to men and women in society on the basis of variables such as economic development (Moore and Shackman 1996; Nuss and Majka 1983), or political systems (Clark and Carvalho 1996; Paxton 1997). Results show that a difference in economic development does not create new roles for women. However, there are indications that political systems fulfill an important function when determining women's role in society and, above all, their access to positions of responsibility traditionally reserved for men.

Pioneering studies, like Friedland and Alford (1990), Hofstede (1991), and Hickson and Pugh (1995), conclude that the cultural and social characteristics of a country have a great influence on the structure of corporate management. Aguilera and Jackson (2003) and Lubatkin et al. (2005, 2007) examine the influence of the institutional context on corporate control mechanisms. These authors recognize the importance of institutional differences, such as legal and cultural factors, in conditioning corporate practices.

Institutional theory assumes that organizations are subject to the institutional environment, which includes the culture in which they operate, and that corporate models are based on the institutional norms present in a specific society (Meyer and Rowan 1977). Such norms can be simply assumed, endorsed by public opinion, or enforced by law (Starbuck 1976). Therefore, these norms inevitably involve normative obligations, but also the shared values and beliefs that contribute to the culture of a society.

In order to survive in competitive environments and acquire legitimacy, organizations must design their organizational structure in line with the set of rules and belief systems that prevail in the country in which they operate. The legal foundation on which every society is based, involves a set of regulatory obligations, as well as values and beliefs that are shared by all members of a society and determine their expected social behavior (DiMaggio and Powell 1983; Scott 1987). Thus, conformity to social expectations is considered key to the survival of a company. Companies are therefore social entities embedded in an institutional order set. They tend to shape their organizational structures to fit the established social order and gain legitimacy. Since culture, as a set of beliefs and values, is one of the institutional forces of any society, the way in which organizational structure are set up may be strongly influenced by cultural values that prevail in a society. Indeed, authors such as Aguilera and Jackson (2003) or Lubatkin et al. (2007) indicate how differences in the institutional environment are the basis for divergences in corporate governance structures.

Li and Harrison (2008) also use institutional theory to develop hypotheses related to the composition and structure of multinational company boards by using the Hofstede framework and data; their definition of board composition is limited to the percentage of outside, or nonmanagement, directors. The results of their study show that culture exerts a significant influence on the structure of boards of directors. Institutional theory has also been used to explore the presence of women on corporate boards in relation to other parameters, such as their representation at other levels of the companies (Bilimoria 2006), their participation as political representatives (Terjesen and Singh 2008), or gender stereotypes and/or discrimination in the labor market (Nelson and Levesque 2007). Given this background, we consider that institutional theory provides a suitable framework to examine which dimensions of the cultural environment are related to the observed between country variations in female representation on boards.

In summary, several reasons justify the use of the cultural dimensions of a country as an explanatory factor. First, comparative studies show that not only is the proportion of women on boards generally low, except in Norway where a quota was adopted, but also this proportion varies between countries. Second, research shows that institutional theory provides a good framework to study the presumed relationship between national cultures and the structure of corporate boards. Thus, the objective of this paper is to relate both lines of research to analyze to what 
extent the culture of a country may explain cross-country variations in terms of board gender diversity.

Several authors have proposed various cultural dimensions or values to describe cultural differences between countries. Hofstede (1980) proposes four cultural dimensions. This author was followed by others whose goal was to improve and extend his work. Work on cultural values by Schwartz (1992), Ingleharts (1977, 2001), Trompenaars (1993), and on the cultural framework proposed in the Global Leadership Organizational Behavior Effectiveness (GLOBE) program (House et al. 2004) have nourished the evolution of the concept. As pointed out by Robbins (2004), over the years the Hofstede cultural dimensions have become the basic theoretical framework to differentiate national cultures. Thus, to examine the relationship between culture, our variable of interest, and board gender diversity, we use the four cultural dimensions identified by Hofstede (1980).

\section{Hypotheses}

Hofstede's cultural model posits that there are cultural differences between countries. This would explain why different countries respond in different ways to the same social phenomenon. These national cultural dimensions were empirically derived through a questionnaire administered to IBM employees from 40 countries in two time periods, namely 1967-1968 and 1971-1973. The aggregation of individual responses by country allowed Hofstede to identify four cultural dimensions that are determinants of a country's culture namely power distance, individualismcollectivism, masculinity and uncertainty avoidance

Power distance refers to the degree to which a society accepts an unequal distribution of power in its institutions and organizations. A high value for this variable indicates that inequalities in power and wealth are more widely accepted. It is a well known fact that women participate less than men in the power structure of organizations such as the board of directors. We therefore expect that countries that manifest a high power distance value, as measured by Hofstede (2000), are more tolerant to the "old boys' club" syndrome and thus to a lower level of female representation on corporate boards. Sealy and Doldor (2009a, b) account for the lack of diversity on boards in part because women are assumed to lack the social capital (or power) to get onto boards. Progression to board-level positions relies on access to the organization's informal networks (old boys' club) in order to keep informed about opportunities beyond the formal channels and to gain support from powerful allies or mentors (mainly men). According to Sealy et al., developing sufficient social capital is crucial to being accepted as a potential board director. We expect the difficulty to be compounded in countries or institutional settings exhibiting high power distance. This leads to our first hypothesis:

H1 The proportion of women on corporate boards is likely to be lower in countries exhibiting high power distance.

The variable individualism measures the degree to which individuals prefer to behave according to individual values rather than to those of the group to which they belong. This variable gages the degree to which a society appreciates individual characteristics such as autonomy, privacy, and the ability to set personal goals, as opposed to being loyal to a group, committing to its norms, and favoring social cohesion. A high value for this variable indicates a more individualistic society. In collective or non-individualistic societies there is often more sensitivity toward the representation of minorities in decision-making positions, so that the voice of a greater range of social groups is represented (Very et al. 1997; Schuler and Rogovsky 1998). These societies would tend to foster more female representation on corporate boards. On this basis, it is argued that high individualism values may be negatively related to the level of female representation on corporate boards. However, it may also be argued that traditional collective values could emphasize traditional gender-specific roles (as in masculinity) in which the boardroom is considered a male domain. Similarly, a high value on this dimension could reflect a commitment to individual human rights, which could include gender equality based on personal merit. Finally, it may be possible that "individualism" manifests in a desire to pursue one's preferences regardless of stereotypes, conventions, etc. That is, women in a country characterized by a relatively high degree of individualism may be more likely to seek to positions - such as board directorships-that they were conventionally denied? We therefore formulate a null hypothesis between PWOB and individualism:

$\mathrm{H} 2$ The proportion of women on corporate boards is not related to the individualism dimension of a country.

For Hofstede (2000), in a "masculine" society, social gender roles are clearly distinct. Men are expected to be assertive, tough, and focused on material success. Values such as performance, assertiveness, success and competitiveness prevail. On the other hand, women are expected to be modest, close to their emotions, and concerned with quality of life, personal relationships, and solidarity. Low levels of "masculinity" are found in societies where social gender roles overlap. Masculinity translates what Sealy et al. (2009a) refers to as persistent gender stereotypesgeneralizations we make about men and women as groups or the characteristics we mentally associate with each gender group. This stereotype engenders a constant gender 
bias in the appraisal of skill and merit in favor of men. Masculine societies define gender roles in a traditional and stereotyped way. In this regard, Konrad et al. (2000), Sealy et al. (2009a), and Oakley (2000) show empirical evidence that the attribution of stereotyped values to women can negatively bias their appointment to corporate boards. We therefore expect a negative association between the level of masculinity of a country and its level of female representation on corporate boards. The third hypothesis is:

H3 The proportion of women on corporate boards is likely to be lower in countries exhibiting high masculinity.

Uncertainty avoidance reflects that the citizens of a country prefer structured over non-structured situations. A high value of uncertainty avoidance indicates a low tolerance for uncertainty and ambiguity, favoring a society oriented toward rules, laws, and controls to reduce the level of uncertainty. Conversely, a low value indicates less concern toward uncertainty and ambiguity, a lesser need for regulations, and more openness to change. Countries with low uncertainty avoidance are more tolerant of diversity in opinions and alternative behaviors and are open to more and larger risks. In this sense, as noted in the literature (Schwartz 1986; Burke 1997; Zelechoski and Bilimoria 2004), women have different experiences than men in the workplace, market, public and community services, so that women bring a different perspective to the debate and decision-making (Billing and Alvesson 1989). As a result, one expects that firms operating in countries with a high capacity to confront change and adapt to new realities, as would be the case with allowing a larger number of women in the power structure of organizations, would show a higher level of female representation on corporate boards. Consequently, the expected relation between the uncertainty avoidance variable and the proportion of women on boards is negative as predicted in the last hypothesis:

H4 The representation of women on corporate boards is likely to be lower in countries exhibiting high uncertainty avoidance.

\section{Methodology}

In this section, we present the sample, the model and the variables.

Sample

The sample for this study is from the BoardEx ${ }^{2}$ database which profiles the corporate boards and individual directors

\footnotetext{
2 BoardEx is a business intelligence service providing data concerning the board of directors and senior management of public and large
}

of public firms across the world. Our initial sample consists of 8,033 firms for which we were able to collect individual board of directors' characteristics such as gender. We do not apply any other filters. Firms for which we could not get information about the variables relevant to the study were eliminated. This elimination process resulted in a sample comprising 7,302 boards from 32 countries which are presented in Table 2 .

Model and Variables

We use an OLS regression model to test whether crosscultural differences between countries have an impact on the proportion of female directors on corporate boards, while controlling for other factors known to affect board composition. The model is as follows:

Proportion of Women on corporate boards $=\mathrm{f}$ (country's culture, control variables)

In the above model, the dependent variable which is the proportion of women on corporate boards $(P W O B)$ is measured as the number of female directors divided by the total number of board members. We use the Hofstede 2000 cultural dimensions discussed in the previous section to measure the main culture of the countries where the sampled firms operate. These dimensions are: power distance, individualism, masculinity, and uncertainty avoidance. Each variable can take a value of 1-100. Table 7 in Appendix shows the mean values of these cultural dimensions per country in our sample as per Hofstede 2000. To control for factors other than the cultural dimensions that have been found to affect the proportion of women on corporate boards, we introduce other variables into the model. The choice of control variables is mainly driven by their explanatory power in a variety of prior studies on women's access to boards of directors.

First, we control for the total number of directors on the board, Board size, as it was found to affect the level of representation by women on such boards (Carter et al. 2003; Coffey and Wang 1998; Erhardt et al. 2003; Hillman and Cannella 2007). Second, we control for situations where a woman is Chair of the board. Considering institutional theory (Bilimoria 2006; Strydom and Au Yong 2012; Palvia et al. 2012), this situation could influence the number of women appointed on the board. The variable

Footnote 2 continued

private companies. It is mainly used by institutional investors, wealth managers, and consultants but more and more as a source for academic research. The BoardEx database holds in-depth profiles of over 500,000 of the world's business leaders. BoardEx was established originally in 2001 by Management Diagnostics Ltd in the UK and has since grown to North America and Asia. 
chairwoman is a dichotomous variable with a value of 1 when the Chair of the board is female and 0 otherwise. Third, we consider the possible effect that firm size might have on $P W O B$. Some studies have found that in small companies women have a greater chance of being promoted in the company's organizational structure (Andre 1995; Bertrand and Hallock 2001). This is largely due to the fact that in smaller companies it is easier to detect the potential of female candidates to serve as board directors. On the contrary, other studies find a positive relationship between the size of a firm and the presence of women on the board of directors (Catalyst 2001; Harrigan 1981; Heidrick and Struggles 1977). This might be explained by the fact that large companies are more likely to use formal evaluation and promotion processes to facilitate women's entry into high-level positions corresponding to their level of education and training. Thus, we do not predict the sign of the relationship between Firm size and the $P W O B$ dependant variable. To proxy for firm size, several authors have used the corporate sales figures (Coffey and Wang 1998; Hambrick and Cannella 2004; Hillman and Cannella 2007; McCormick Hyland and Marcellino 2002; Sander and Boivie 2004), total assets (Carter et al. 2003; Erhardt et al. 2003; Peng 2004), or the total number of employees (Coffey and Wang 1998; Konrad and Mangel 2000; Smith 2007). We use the logarithm of sales to measure Firm size in order to avoid problems of scale in the distribution of this variable.

Fourth, our model controls for firm performance, labeled profitability, as prior studies conclude that pluralism including gender diversity on boards entails a variety of points of view that leads to better decision-making and performance (Ben Amar et al. 2013), and that financially successful firms may select more women directors (Carter et al. 2010). Profitability is computed as net profit divided by total equity as in other international studies (Adler 2001; Catalyst 2004; Carter et al. 2003).

Fifth, we control for the legislation or regulation adopted in various countries to increase female representation on corporate boards. The main tool used to promote gender equality policies is the national code of good governance. The dichotomous variable, code, takes the value 1 when the code of good governance of a country specifically refers to the promotion of more women on boards and 0 when such reference is not made. We use the code in force as of 2010 as some countries have amended their codes of good governance several times.

Finally, as Brewer (2001) and McDonald (2000) indicate, the type of business a company engages in may affect the opportunities for women to take on more responsibilities. Therefore, the sampled firms are classified into 10 sectors of activity: energy, materials, industrial, consumer discretionary, consumer staples, health care, financial, information technology, telecommunication services, and utilities.

\section{Results and Analyses}

In this section, we first present and discuss descriptive statistics relative to women's participation on boards for our total sample. The statistics are also broken down by country. We then present and discuss the results of our multivariate analysis aimed at determining if there is a cultural bias in the appointment of female directors around the world.

Descriptive Analysis of Women's Participation on Corporate Boards

Table 1 presents data on the number of directors on boards, classified according to their gender. The average number of directors is 9.63 , of which only $8 \%$ are women. This figure is consistent with previous research, which reveals that women are scarcely represented in upper-level corporate positions.

Table 2 presents descriptive statistics about board size and gender representation by country. The proportion of female directors is higher than the $8 \%$ average in Sweden (23\%), Finland (20\%), South Africa (17\%), Israel (15\%), Denmark, France, and Luxemburg (10\%), and Belgium and Spain (9\%). Most of these countries have imposed or are considering imposing quotas or other constraints on their public firms to promote gender diversity on boards. We specifically control for this effect of regulation in the multivariate analyses in "Multivariate Analysis" section. The following countries exhibit below-average women participation in corporate boards: Japan (2\%), New Zealand (4\%), Austria, India, Russia, and Switzerland (5\%), Australia, Brazil, China, Germany, Hong Kong, Italy, Portugal, Singapore, and the United Kingdom (6\%), and Greece, Holland, and Ireland (7\%).

Table 3 shows the level of female presence on corporate boards per country. As could be expected because of current or forthcoming regulation, countries like Denmark,

Table 1 Composition of the board of directors

\begin{tabular}{lllll}
\hline Variable & Minimum & Maximum & Mean & $\begin{array}{l}\text { Standard } \\
\text { deviation }\end{array}$ \\
\hline Size of the board & 1 & 54 & 9.63 & 4.43 \\
Men directors & 1 & 51 & 8.76 & 3.92 \\
Women directors & 0 & 14 & 0.87 & 1.15 \\
$\begin{array}{l}\text { \% women } \\
\text { directors }\end{array}$ & 0 & 75 & 8 & 9 \\
\hline
\end{tabular}


Table 2 Board size and gender representation by country

\begin{tabular}{|c|c|c|c|c|}
\hline Country & $\begin{array}{l}\text { Size of } \\
\text { the board }\end{array}$ & $\begin{array}{l}\text { Men } \\
\text { directors }\end{array}$ & $\begin{array}{l}\text { Women } \\
\text { directors }\end{array}$ & $\begin{array}{l}\% \text { women } \\
\text { directors }\end{array}$ \\
\hline Australia & 6.50 & 6.08 & 0.41 & 5.64 \\
\hline Austria & 12.61 & 12.03 & 0.58 & 4.59 \\
\hline Belgium & 8.74 & 7.98 & 0.75 & 8.58 \\
\hline Brazil & 10.92 & 10.25 & 0.67 & 6.03 \\
\hline Canada & 9.04 & 8.17 & 0.87 & 8.43 \\
\hline China & 10.53 & 10.00 & 0.53 & 5.50 \\
\hline Denmark & 10.48 & 9.48 & 1.00 & 9.78 \\
\hline Finland & 10.29 & 8.06 & 2.23 & 19.88 \\
\hline France & 10.69 & 9.64 & 1.05 & 10.25 \\
\hline Germany & 13.55 & 12.60 & 0.95 & 5.95 \\
\hline Greece & 9.46 & 8.79 & 0.67 & 7.31 \\
\hline Holland & 8.75 & 8.06 & 0.69 & 6.59 \\
\hline Hong Kong & 12.15 & 11.20 & 0.95 & 6.18 \\
\hline India & 10.39 & 9.83 & 0.56 & 5.29 \\
\hline Ireland & 9.15 & 8.61 & 0.54 & 6.55 \\
\hline Israel & 7.66 & 6.58 & 1.08 & 15.40 \\
\hline Italy & 11.78 & 11.10 & 0.67 & 6.28 \\
\hline Japan & 12.71 & 12.50 & 0.21 & 2.08 \\
\hline Luxembourg & 8.42 & 7.58 & 0.83 & 10.17 \\
\hline Malaysia & 8.17 & 7.52 & 0.65 & 7.73 \\
\hline Mexico & 17.12 & 15.76 & 1.35 & 7.87 \\
\hline New Zealand & 7.22 & 6.89 & 0.33 & 4.21 \\
\hline Poland & 12.54 & 11.46 & 1.08 & 8.30 \\
\hline Portugal & 10.55 & 9.95 & 0.59 & 5.68 \\
\hline Russia & 13.33 & 12.61 & 0.72 & 4.73 \\
\hline Singapore & 10.20 & 9.60 & 0.60 & 6.09 \\
\hline South Africa & 11.00 & 9.20 & 1.80 & 16.73 \\
\hline Spain & 12.03 & 10.87 & 1.16 & 9.16 \\
\hline Sweden & 9.97 & 7.70 & 2.27 & 23.25 \\
\hline Switzerland & 9.30 & 8.70 & 0.59 & 5.11 \\
\hline United Kingdom & 6.73 & 6.28 & 0.46 & 6.19 \\
\hline United States & 10.17 & 9.22 & 0.95 & 8.04 \\
\hline Mean & 10.38 & 9.51 & 0.87 & 8.24 \\
\hline
\end{tabular}

Finland, France, Israel, South Africa, and Sweden exhibit a higher-than-average proportion of female directors. Further, when there is at least one female director, Finland, Sweden and Mexico have an average number of female directors which is close to the critical mass of 3 identified by Konrad et al. (2008). However, it is also worth noting that Germany, Mexico, Poland, and the United States which exhibits lower-than-average proportion of female representation on boards have an above average percentage of boards with at least one woman. Finally, Australia, Japan, New Zealand, and the United Kingdom have the highest percentage of boards with no female director. The case of Belgium stands out with a majority of corporate boards $(54.7 \%)$ with no female director despite an above average proportion of female directors on boards with at least one female director.

Table 4 presents a contingent analysis of the existence or not of a national code of corporate governance encouraging the participation of women in corporate boards and other variables relative to the board. The existence of such codes is bound to affect board gender diversity. Seven countries in our sample have such a national code encouraging gender diversity: Denmark, Finland, Luxembourg, Holland, Ireland, Spain, and Sweden. Panel A indicates that $42.3 \%$ of the firms (548) operating in these countries have at least one woman on their board. In the absence of a national code of corporate governance or when the code does not refer to gender diversity, the proportion of firms with at least one woman on board increases to $52.5 \%$ (3,154 firms). This difference is statistically significant $\left(\chi^{2}=43,861 ; p<0.001\right)$. Therefore, contrary to our expectations, codes of governance do not appear to significantly influence the presence of women on corporate boards.

Furthermore, as can be seen in Panel B of Table 4, references to gender diversity in codes of governance do not result in greater overall female representation on corporate boards, as the percentage of women is the same in both cases $(8 \%)$. Finally, the average size of corporate boards, as well as the average number of women are significantly higher when there is no reference to gender diversity in the national code of governance.

Multivariate Analysis

Table 5 presents the results of the multivariate OLS regression models used to investigate the hypothesized relationship between culture, the variable of interest, and the proportion of female directors, while controlling for other variables that could affect this proportion. All coefficients are standardized which allows to compare them.

To better see the effect of culture in the subsequent models, model 1 only includes the control variables. The level of women's participation on corporate boards is significantly higher for companies whose boards are larger, for companies where the Chair is a woman and for companies that are larger as measured by sales. This evidence brings to light a series of important issues. First, with reference to the size of the board, we interpret its positive relationship with the PWOB as greater women representation being achieved by increasing the total number of directors.

Second, female representation on corporate boards is greater for those companies where the Chair of the board is a woman. Finally, there is a positive relation between firm size and $P W O B$. These empirical relationships are 
Table 3 Female presence on corporate boards per country

\begin{tabular}{|c|c|c|c|c|c|c|c|}
\hline \multirow[t]{2}{*}{ Country } & \multicolumn{2}{|c|}{$\begin{array}{l}\text { Boards with no } \\
\text { women directors }\end{array}$} & \multicolumn{2}{|c|}{$\begin{array}{l}\text { Boards with at } \\
\text { least one women } \\
\text { director }\end{array}$} & \multirow{2}{*}{$\begin{array}{l}\text { Total number } \\
\text { of women } \\
\text { directors } \\
\text { Number }\end{array}$} & \multirow{2}{*}{$\begin{array}{l}\text { Average number } \\
\text { of women } \\
\text { directors } \\
\text { Number }\end{array}$} & \multirow{2}{*}{$\begin{array}{l}\text { Proportion } \\
\text { of women } \\
\text { directors } \\
\%\end{array}$} \\
\hline & Number & $\%$ & Number & $\%$ & & & \\
\hline Australia & 189 & 67 & 93 & 33 & 117 & 1.26 & 5.6 \\
\hline Austria & 18 & 58.1 & 13 & 41.9 & 18 & 1.38 & 4.6 \\
\hline Belgium & 29 & 54.7 & 24 & 45.3 & 40 & 1.67 & 8.6 \\
\hline Brazil & 7 & 58.3 & 5 & 41.7 & 8 & 1.6 & 6.0 \\
\hline Canada & 164 & 51.6 & 154 & 48.4 & 277 & 1.8 & 8.4 \\
\hline China & 9 & 60 & 6 & 40 & 8 & 1.33 & 5.5 \\
\hline Denmark & 5 & 23.8 & 16 & 76.2 & 21 & 1.31 & 9.8 \\
\hline Finland & 4 & 12.9 & 27 & 87.1 & 69 & 2.56 & 19.9 \\
\hline France & 81 & 35.2 & 149 & 64.8 & 241 & 1.62 & 10.3 \\
\hline Germany & 77 & 48.7 & 81 & 51.3 & 150 & 1.85 & 6.0 \\
\hline Greece & 14 & 58.3 & 10 & 41.7 & 16 & 1.6 & 7.3 \\
\hline Hong Kong & 11 & 55 & 9 & 45 & 19 & 2.11 & 6.2 \\
\hline India & 99 & 57.9 & 72 & 42.1 & 95 & 1.32 & 5.3 \\
\hline Ireland & 22 & 53.7 & 19 & 46.3 & 22 & 1.16 & 6.6 \\
\hline Israel & 8 & 8.2 & 99 & 91.8 & 105 & 1.18 & 15.4 \\
\hline Italy & 34 & 50.7 & 33 & 49.3 & 45 & 1.36 & 6.3 \\
\hline Japan & 29 & 85.3 & 5 & 14.7 & 7 & 1.4 & 2.1 \\
\hline Luxembourg & 6 & 50 & 6 & 50 & 10 & 1.67 & 10.2 \\
\hline Malaysia & 13 & 56.5 & 10 & 43.5 & 15 & 1.5 & 7.7 \\
\hline Mexico & 8 & 47.1 & 9 & 52.9 & 23 & 2.56 & 7.9 \\
\hline Holland & 37 & 56.9 & 28 & 43.1 & 45 & 1.61 & 6.6 \\
\hline New Zealand & 6 & 66.7 & 3 & 33.3 & 3 & 1 & 4.2 \\
\hline Poland & 2 & 15.4 & 11 & 84.6 & 14 & 1.27 & 8.3 \\
\hline Portugal & 13 & 59.1 & 9 & 40.9 & 13 & 1.44 & 5.7 \\
\hline Russia & 10 & 55.6 & 8 & 44.4 & 13 & 1.63 & 4.7 \\
\hline Singapore & 11 & 55 & 9 & 45 & 12 & 1.33 & 6.1 \\
\hline South Africa & 8 & 11.3 & 63 & 88.7 & 128 & 2.03 & 16.7 \\
\hline Spain & 20 & 32.3 & 42 & 38.7 & 72 & 1.71 & 9.2 \\
\hline Sweden & 4 & 4.3 & 89 & 95.7 & 211 & 2.37 & 23.3 \\
\hline Switzerland & 37 & 57.8 & 27 & 42.2 & 38 & 1.41 & 5.1 \\
\hline United Kingdom & 648 & 66.9 & 321 & 33.1 & 441 & 1.37 & 6.2 \\
\hline United States & 1977 & 46.6 & 2262 & 53.4 & 4033 & 1.78 & 8.2 \\
\hline Mean & 113 & 47.5 & 116 & 51.6 & 198 & 1.6 & 8.2 \\
\hline
\end{tabular}

maintained in all estimated models and can therefore be considered robust. On the other hand, profitability and corporate governance codes do not appear to be related to gender diversity.

Models 2, 3, 4, and 5 introduce variables to reflect the various cultural dimensions characterizing the countries in which our sample firms operate. To measure these variables, we use the values that Hofstede (2000) assigns to different cultural dimensions. Model 6 integrates all cultural dimensions. Our hypotheses are confirmed for two of the three cultural dimensions for which we propose directional hypotheses: power distance and masculinity.
The sign of the coefficient for power distance is negative and significant in model 2 and model 6. As defined, the cultural dimension of power distance measures the extent to which the less powerful members of society expect and accept that power is distributed unequally. Hence, our results support Hypothesis 1, namely that the proportion of women on corporate boards is likely to be lower in countries where power distance is greater. In countries with high power distance, inequality between men and women is tolerated, therefore underrepresentations of women on boards is not considered a problem. This in turn fosters a considerable cultural barrier for women in the selection process of new directors. 
Table 4 National corporate governance code encouraging gender equality

\begin{tabular}{|c|c|c|c|}
\hline \multirow[t]{2}{*}{ Variables } & \multicolumn{2}{|l|}{ Existence } & \multirow[t]{2}{*}{ Total } \\
\hline & No & Yes & \\
\hline \multicolumn{4}{|l|}{$\begin{array}{l}\text { Panel A: number } \\
\text { of boards }(\%)\end{array}$} \\
\hline $\begin{array}{l}\text { Board with } \\
\text { no woman }\end{array}$ & $2,854(47.5 \%)$ & $746(57.7 \%)$ & 3,600 \\
\hline $\begin{array}{l}\text { Board with at } \\
\text { least one } \\
\text { woman }\end{array}$ & $3,154(52.5 \%)$ & $548(42.3 \%)$ & 3,702 \\
\hline Total & 6,008 & 1,294 & 7,302 \\
\hline Panel B & & & $\begin{array}{l}\text { T statistic } \\
\text { (significance }\end{array}$ \\
\hline $\begin{array}{l}\text { Size of the } \\
\text { Board }\end{array}$ & 10.08 & 7.56 & $18.972 * * *$ \\
\hline $\begin{array}{l}\text { Women } \\
\text { directors }\end{array}$ & 0.91 & 0.69 & $6.140 * * *$ \\
\hline $\begin{array}{l}\% \text { women } \\
\text { directors }\end{array}$ & 0.08 & 0.08 & 0.135 \\
\hline
\end{tabular}

To test hypothesis 2 , the variable individualism is introduced in models 3 and 6. As hypothesized, PWOB does not appear to be affected by the individualism (collectivism) cultural dimension.
The masculinity dimension is introduced in models 4 and 6. The coefficient of masculinity is statistically and negatively related to PWOB which is in conformity with our third hypothesis stating that the PWOB is likely to be lower in countries where the masculinity dimension is greater. This dimension refers to the role division between genders. According to Hofstede (1980), in "masculine" societies, gender roles are more clearly differentiated, while in feminine societies there is more ambiguity regarding gender roles. Assuming that candidate women are as qualified and experienced as their male counterparts, in masculine societies, the assessment of skill and merit is biased. This bias is caused by persistent gender stereotypes-generalizations we make about men and women as groups. Hence similar behaviors are perceived and valued differently depending on whether they are displayed by men or women, and therefore the accumulation of these stereotype effects can create barriers for women to join boards.

The standardized coefficients for masculinity are larger than those of power distance which indicates that masculinity has a greater impact on PWOB. Furthermore, the absolute value of the impact of these variables on PWOB is not negligible. For instance, a 30 unit decrease in masculinity is associated with an increase of $4.41 \%$ of the PWOB value. The coefficient of masculinity is greater than
Table 5 OLS analysis of the factors presumed to affect the proportion of women on corporate boards using Hofstede's cultural dimensions

$p$ values in parentheses: $* * * p<0.01$

\begin{tabular}{|c|c|c|c|c|c|c|}
\hline Variable & Model 1 & Model 2 & Model 3 & Model 4 & Model 5 & Model 6 \\
\hline Board size & $\begin{array}{l}0.173 \\
(0.00)^{* * *}\end{array}$ & $\begin{array}{l}0.161 \\
(0.00)^{* * *}\end{array}$ & $\begin{array}{l}0.169 \\
(0.00)^{* * *}\end{array}$ & $\begin{array}{l}0.182 \\
(0.00)^{* * *}\end{array}$ & $\begin{array}{l}0.173 \\
(0.00)^{* * *}\end{array}$ & $\begin{array}{l}0.167 \\
(0.00)^{* * *}\end{array}$ \\
\hline Chairwoman & $\begin{array}{l}0.237 \\
(0.00)^{* * *}\end{array}$ & $\begin{array}{l}0.239 \\
(0.00)^{* * *}\end{array}$ & $\begin{array}{l}0.238 \\
(0.00)^{* * *}\end{array}$ & $\begin{array}{l}0.236 \\
(0.00)^{* * *}\end{array}$ & $\begin{array}{l}0.237 \\
(0.00)^{* * *}\end{array}$ & $\begin{array}{l}0.238 \\
(0.00)^{* * *}\end{array}$ \\
\hline Firm size & $\begin{array}{l}0.079 \\
(0.00)^{* * *}\end{array}$ & $\begin{array}{l}0.110 \\
(0.00)^{* * *}\end{array}$ & $\begin{array}{l}0.091 \\
(0.00)^{* * *}\end{array}$ & $\begin{array}{l}0.051 \\
(0.00)^{* * *}\end{array}$ & $\begin{array}{l}0.080 \\
(0.00)^{* * *}\end{array}$ & $\begin{array}{l}0.089 \\
(0.00)^{* * *}\end{array}$ \\
\hline Profitability & $\begin{array}{l}0.002 \\
(0.88)\end{array}$ & $\begin{array}{l}0.004 \\
(0.74)\end{array}$ & $\begin{array}{l}0.002 \\
(0.85)\end{array}$ & $\begin{array}{l}0.003 \\
(0.71)\end{array}$ & $\begin{array}{l}0.002 \\
(0.88)\end{array}$ & $\begin{array}{l}0.006 \\
(0.58)\end{array}$ \\
\hline Code & $\begin{array}{l}0.006 \\
(0.44)\end{array}$ & $\begin{array}{l}0.003 \\
(0.65)\end{array}$ & $\begin{array}{l}0.005 \\
(0.46)\end{array}$ & $\begin{array}{l}0.002 \\
(0.72)\end{array}$ & $\begin{array}{l}0.004 \\
(0.57)\end{array}$ & $\begin{array}{l}0.004 \\
(0.77)\end{array}$ \\
\hline Power distance & - & $\begin{array}{l}-0.082 \\
(0.00)^{* * *}\end{array}$ & - & - & - & $\begin{array}{l}-0.096 \\
(0.00)^{* * *}\end{array}$ \\
\hline Individualism & - & - & $\begin{array}{l}0.004 \\
(0.32)\end{array}$ & - & - & $\begin{array}{l}0.010 \\
(0.32)\end{array}$ \\
\hline Masculinity & - & - & - & $\begin{array}{l}-0.129 \\
(0.00)^{* * *}\end{array}$ & & $\begin{array}{l}-0.147 \\
(0.00)^{* * *}\end{array}$ \\
\hline Uncertainty & - & - & - & & $\begin{array}{l}-0.006 \\
(0.73)\end{array}$ & $\begin{array}{l}-0.010 \\
(0.45)\end{array}$ \\
\hline Sector control & YES & YES & YES & YES & YES & YES \\
\hline Adjusted $R^{2}$ & 0.106 & 0.111 & 0.105 & 0.121 & 0.105 & 0.140 \\
\hline$F$-Test & 171.609 & 151.760 & 144.000 & 167.972 & 143.010 & 122.490 \\
\hline$p$ value & $(0.00)^{* * *}$ & $(0.00)^{* * *}$ & $(0.00)^{* * *}$ & $(0.00)^{* * *}$ & $(0.00)^{* * *}$ & $(0.00)^{* * *}$ \\
\hline Mean VIF & 1.27 & 1.30 & 1.31 & 1.25 & 1.27 & 1.49 \\
\hline
\end{tabular}


Table 6 OLS analysis of the factors presumed to affect the proportion of women on corporate boards using

GLOBE's cultural dimensions

$p$ values in parentheses:

$* * *<0.01, * *<0.05$

firm size and just slightly lower than board size, two variables that are known to be associated with PWOB (Heidrick and Struggles 1977; Harrigan 1981; Andre 1995; Coffey and Wang 1998; Bertrand and Hallock 2001, Catalyst 2001; Carter et al. 2003; Erhardt et al. 2003; Hillman and Cannella 2007). Although not as high, the coefficient of power distance is larger than that of firm size. In sum, in terms of magnitude, we conclude that these cultural dimensions do have a tangible impact on PWOB.

Finally, the variable uncertainty avoidance is introduced in models 5 and 6 . We do not find support for hypothesis 4 , according to which the proportion of women on boards would be lower in countries that tend to avoid uncertainties. As the power and masculinity dimensions tested in $\mathrm{H} 1$ and $\mathrm{H} 3$ happen to correspond to widely held stereotypes about gender differences, the stronger impact of these cultural dimensions than for the individualism- collectivism (H2) and uncertainty avoidance (H4) ones are not overly surprising.

Robustness Analysis

To test the robustness of our results, we run a series of additional analyses. These include different measurements to define the cultural dimensions and the dependent variable and a reduced sample covering the European Union. The results, which are not all tabulated here for the sake of conciseness, are similar to those discussed in "Multivariate Analysis" with masculinity and power distance being the only two cultural dimensions associated with PWOB.

Hofstede' scores have been proven to be quite stable over decades, but the data were collected over 30 years ago. Hofstede (2001) highlights that the forces that cause cultures to shift tend to be global or continent-wide. This means that they affect many countries at the same time, so that if their cultures shift, they shift together, and their relative positions remain the same. We first test the robustness of this proxy by using the cultural dimensions developed in the study conducted by GLOBE (House et al. 2004). The GLOBE research program conducted a study whose main goal was to describe, understand, and predict the influence of cultural variables on leadership, management processes, and effectiveness around the world. This program began in 1993 and used data from 825 organizations from 62 countries. Nine dimensions were identified, namely: performance orientation, future orientation, gender egalitarianism, assertiveness, institutional collectivism, ingroup collectivism, power distance, humane orientation, and uncertainty avoidance. Table 8 in Appendix shows the definition of these dimensions and the scores for the countries included in our sample.

The results obtained with this proxy (see Table 6) confirm the ones obtained using the Hofstede measure, namely that power distance and gender egalitarianism, a dimension similar to Hofstede's masculinity, are associated with $P W O B .^{3}$

Second, as the ratio of women on board, $P W O B$, fluctuates to a great extent among countries and may be affected by increasing either the number of women or the size of the board (denominator), we replace PWOB by a more conservative dichotomous variable taking the value of 1 when the board includes at least one woman and 0 otherwise. Results are similar to the ones obtained with the continuous variable.

\footnotetext{
${ }^{3}$ We used the same sample except for Belgium and Luxemburg which were removed because the GLOBE study did not cover these countries.
} 
Third, we rerun the model 6 , but only for companies with at least one woman on the board. One would assume that there would be more gender equality sensitivity within these companies. Results for this reduced sample are similar to the original results.

Fourth, we rerun model 6 while only considering countries that are members of the European Union (EU). This analysis allows us to examine the effect of culture on PWOB within the EU where the debate about female representation on boards is particularly intense as evidenced by the regulation being put in place by several of EU countries. Further, most of the cultures in the EU abide by the same legal and institutional guidelines. Again, the results obtained for EU country corporate boards reveal that power distance and masculinity explain the variations in women's access to corporate boards. Finally, we rerun the model while only keeping the following Anglo-Saxon countries (Australia, Canada, Ireland, New Zealand, United Kingdom, United States), which we deemed to belong to similar cultures. As expected, the results reaffirm that the power distance and masculinity cultural dimensions are associated with PWOB.

\section{Conclusions}

According to several sources, women are underrepresented in corporate boards worldwide. This represents an important ethical issue which many countries, especially in Europe, are trying to resolve by a variety of means, including legal quotas. Past research is not conclusive and does not thoroughly account for the determinants of the persistent bias in favor of the appointment of more men than women directors. Furthermore, it stands out from the past professional and academic literature as well as from our own analysis that the proportion of women on boards is far from being similar across countries. This leads us to investigate if there is a cultural effect given institutional isomorphism (DiMaggio and Powell 1983). The institutional environment of a country which includes its national culture determines the set of beliefs and values that, to greater or lesser degree, are shared by its citizens. These shared beliefs can specifically influence many social processes and engender the creation of stereotypes and roles associated with gender. In turn, these stereotypes might condition the professional progress of women.

As evidenced by numerous studies, there are important differences between the culture of different countries (Hofstede 1980; Schwartz 1992; Ingleharts 1977, 2001; Trompenaars 1993; House et al. 2004), and as supports institutional theory, these cultural differences are the basis for the differences in the structures of corporate governance at the international level (Aguilera and Jackson 2003; Lubatkin et al. 2007).
To explore this issue, our study compares the level of representation of women on corporate boards across 32 countries. Our analysis looks specifically into whether the prevailing culture of a country influences the ability of women to access boards' directorships.

To provide a specific and relatively objective evaluation of the culture of a country, we use the cultural dimensions proposed in the seminal work of Hofstede (1980), as those measures are still considered the best proxy for culture despite some critics. Our results indeed reveal that certain aspects of the culture of a country contribute to determine the level of representation of women on corporate boards of directors. Specifically, two of the four cultural dimensions suggested by Hofstede (1980) (or two of the three dimensions for which we propose directional hypotheses) stand out. The first refers to "power distance" according to which firms operating in countries where an unequal distribution of power in institutions and organizations is accepted, tend to have a lesser proportion of women represented on their corporate boards. The second cultural dimension termed "masculinity" indicates that when societal values associated with the masculine role prevail, the proportion of women on corporate boards is generally lower.

This study is subject to some caveats. Despite the extensive and conclusive use of Hofstede's cultural model in previous studies, it has been the subject of several critiques. First, the definitions of cultural dimension are extracted from only one company. Second, the culture of a country is a complex concept that may be very difficult to capture quantitatively in four dimensions. To alleviate those limits, we use other measures as robustness checks with similar results. Third, we have assumed that the effect of the cultural dimensions on female representation on corporate boards are independent of each other, but they may interact in a complex way that was not investigated in this study. Finally, although the $p$ values are high, our models show low R squared. Future research should consider using more comprehensive models to increase the explanatory power. For instance, we assumed that the level of education and experience is the same for male and female directors in our sample.

Acknowledgments The second and third authors gratefully acknowledge financial support from the Social Sciences and Humanities Research Council of Canada (Grant No. 410-03-1046), the Institute for Governance in Public and Private Organizations and, respectively, the CGA Professorship in Strategic Financial Information and the Stephen A. Jarislowsky Chair in Governance. The authors are also grateful to the anonymous reviewers for their valuable comments.

\section{Appendix}

See Tables 7,8 . 
Table 7 Scores of cultural dimensions by country Hofstede (2000)

\begin{tabular}{|c|c|c|c|c|}
\hline Country & Power distance & Individualism & Masculinity & Uncertainty avoidance \\
\hline Australia & 36 & 90 & 61 & 51 \\
\hline Austria & 11 & 55 & 79 & 70 \\
\hline Belgium & 65 & 75 & 54 & 94 \\
\hline Brazil & 69 & 38 & 49 & 76 \\
\hline Canada & 39 & 80 & 52 & 48 \\
\hline China & 80 & 20 & 66 & 30 \\
\hline Denmark & 18 & 74 & 16 & 23 \\
\hline Finland & 33 & 63 & 26 & 59 \\
\hline France & 68 & 71 & 43 & 86 \\
\hline Germany & 35 & 67 & 66 & 65 \\
\hline Greece & 60 & 35 & 57 & 112 \\
\hline Holland & 38 & 80 & 14 & 53 \\
\hline Hong Kong & 68 & 25 & 57 & 29 \\
\hline India & 77 & 48 & 56 & 40 \\
\hline Ireland & 28 & 70 & 68 & 35 \\
\hline Israel & 13 & 54 & 47 & 81 \\
\hline Italy & 50 & 76 & 70 & 75 \\
\hline Japan & 54 & 46 & 95 & 92 \\
\hline Luxembourg & 39.1 & 60.9 & 45.8 & 68 \\
\hline Malaysia & 104 & 26 & 50 & 36 \\
\hline Mexico & 81 & 30 & 69 & 82 \\
\hline New Zealand & 22 & 79 & 58 & 49 \\
\hline Poland & 68 & 60 & 64 & 93 \\
\hline Portugal & 63 & 27 & 31 & 104 \\
\hline Russia & 93 & 39 & 36 & 95 \\
\hline Singapore & 74 & 20 & 48 & 8 \\
\hline South Africa & 49 & 65 & 83 & 49 \\
\hline Spain & 57 & 51 & 42 & 86 \\
\hline Sweden & 31 & 71 & 5 & 29 \\
\hline Switzerland & 34 & 68 & 70 & 58 \\
\hline United Kingdom & 35 & 89 & 66 & 35 \\
\hline United States & 40 & 91 & 62 & 46 \\
\hline
\end{tabular}

Power distance the degree to which a society accepts an unequal distribution of power in its institutions and organizations

Individualism the degree to which individuals prefer to behave according to individual values rather than to those of the group to which they belong

Masculinity refers to the distribution of emotional roles between the genders

Uncertainty avoidance indicates to what extent a culture programs its members to feel either uncomfortable or comfortable in unstructured situations 


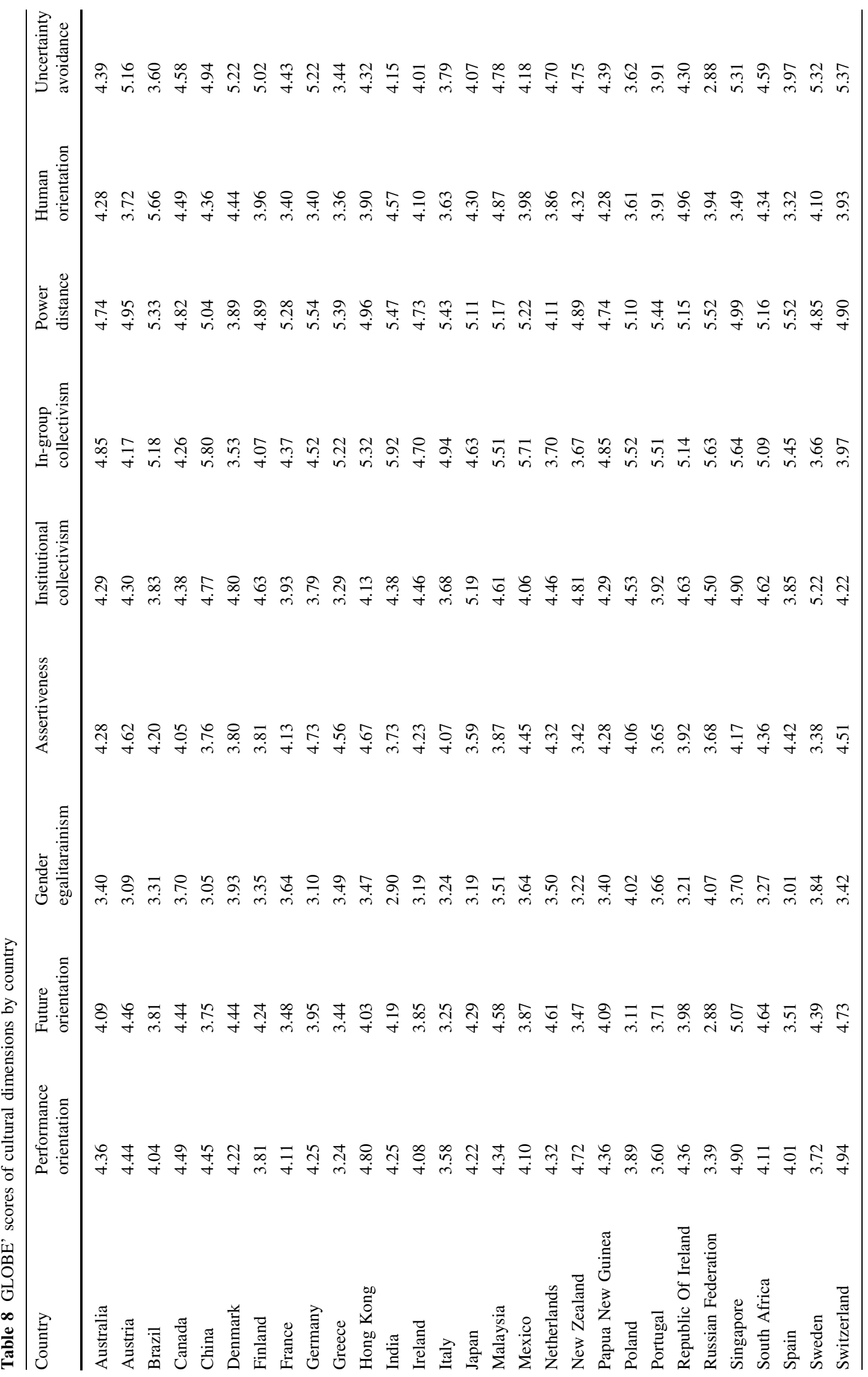




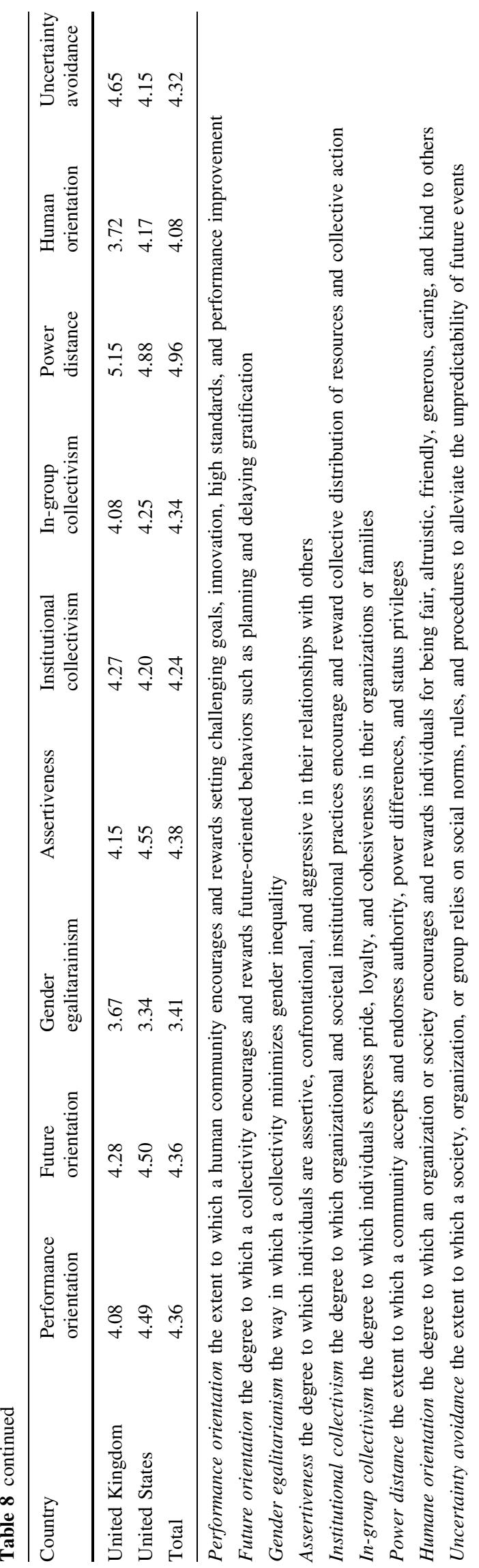

\section{References}

Adler, R. D. (2001). Women in the executive suite correlate to high profits. Working paper. Conference Equal Pay is value adding. ECWT. European Center for women and Technology. Copenhagen.

Aguilera, R. V., \& Jackson, G. (2003). The cross-national diversity of corporate governance dimensions and determinants. Academy of Management Journal, 28(3), 447-465.

Andre, R. (1995). Diversity in executive networks: A national study of women's representation in private sector economic development. Journal of Managerial Issues, 7(3), 306-322.

Ben Amar, W., Francoeur, C., Hafsi, T., \& Labelle, R. (2013). What makes better boards? A closer look at diversity and ownership. British Journal of Management, 24, 85-101.

Bertrand, M., \& Hallock, K. F. (2001). The gender gap in top corporate jobs. Industrial and Labor Relations Review, 55(1), $3-21$.

Bilimoria, D. (2006). The relationship between women corporate directors and women corporate officers. Journal of Managerial Issues, 18(1), 47-61.

Billing, Y. D., \& Alvesson, M. (1989). Four ways of looking at women and leadership. Scandinavian Journal of Management, 5 , 63-80.

Brewer, B. (2001). Women building presence in non-traditional fields. Business Woman, 15, 11-40.

Burgess, Z., \& Tharenou, P. (2002). Women board directors: Characteristics of the few. Journal of Business Ethics, 37, 39-49.

Burke, R. J. (1997). Women on corporate boards of directors. A needed resource. Journal of Business Ethics, 16(9), 909-915.

Carter, D. A., D'Souza, F., Simkins, B. J., \& Simpson, W. G. (2010). The gender and ethnic diversity of US boards and board committees and firm financial performance. Corporate Governance: An International Review, 8(5), 396-414.

Carter, D. A., Simkins, B. J., \& Simpson, W. G. (2003). Corporate governance, board diversity, and firm value. The Financial Review, 38, 33-53.

Catalyst, (2001). Catalyst census of women board directors. New York: Catalyst.

Catalyst. (2004). The bottom line: Connecting corporate performance and gender diversity. www.Catalystwomen.org.

Catalyst. (2005-2008). Catalyst census of women board directors of the Fortune 500. www.Catalystwomen.org.

Catalyst. (2011-2012). Increasing gender diversity on boards: Current index of formal approaches. Catalyst, New York.

Clark, R., \& Carvalho, J. (1996). Female revolt revisited. International Review of Modern Sociology, 26, 27-42.

Coffey, B. S., \& Wang, J. (1998). Board diversity and managerial control as predictors of corporate social performance. Journal of Business Ethics, 17, 1595-1603.

Dalton, D. R., Daily, C. M., Ellstrand, A. E., \& Johnson, J. L. (1998). Meta-analytic reviews of board composition, leadership structure, and financial performance. Strategic Management Journal, 19(3), 269-290.

Davies. (2011). UK Corporate Governance Code. Financial Reporting Council.

Dimaggio, P. J., \& Powell, W. (1983). The iron cage revisited institutional isomorphism and collective rationality in organizational fields. American Sociological Review, 48, 147-160.

Erhardt, N. L., Werbel, J. D., \& Shrader, C. B. (2003). Board of director diversity and firm financial performance. Corporate Governance, 11(2), 102-111.

European Board Diversity Analysis. (2010). Is it getting easier to find women on European boards? Egon Zehnder International. London. www.egonzehnder.com. 
Financial Reporting Council. (2011). UK Corporate Governance Code. Financial Reporting Council. London. www.frc.org.uk.

Friedland, R., \& Alford, R. R. (1990). Bringing society back in symbols, practices and institutional contradictions. In W. W. Powell \& P. J. Di Maggio (Eds.), The new institutionalism in organization analysis (pp. 232-263). Chicago, IL: University of Chicago Press.

Gray, S. J. (1988). Towards a theory of cultural influence on the development of accounting systems internationally. ABACUS, 24, $1-15$.

Guiso, L., Sapienza, P., \& Zingales, L. (2006). Does culture affect economic outcomes? Social Science Research Network. CEPR Discussion Paper No. 5505.

Hambrick, D. C., \& Cannella, A. A. (2004). CEOs who have COOs: Contingency analysis of an unexplored structural form. Strategic Management Journal, 25, 959.

Harrigan, K. R. (1981). Numbers and positions of women elected to corporate boards. Academy of Management Journal, 24(3), $619-625$.

Haslam, S. A., Ryan, M. K., Kulich, C., Trojanowski, G., \& Atkins, C. (2010). Investing with prejudice: The relationship between women's presence on company boards and objective and subjective measures of company performance. British Journal of Management, 21, 484-497.

Hausmann, R., Tyson, L. D., \& Zahidi, S. (2010). The global gender gap report 2010. Geneva, Switzerland: World Economic Forum.

Heidrick \& Struggles. (1977). The changing board profile of the board of directors. Chicago, IL: Heidrick \& Struggles.

Hickson, D. J., \& Pugh, D. S. (1995). Management worldwide: The impact of societal culture on organizations around the globe. London: Penguin.

Hillman, A. J., \& Cannella, A. (2007). Organizational predictors of women on corporate boards. Academy of Management Journal, 50(4), 941-952.

Hofstede, G. (1980). Culture's consequences: International differences in work-related values. Beverly Hills, CA: Sage.

Hofstede, G. (1991). Cultures and organizations. Software of the mind. London: McGraw-Hill.

Hofstede, G. (2000). Culture's consequences: Comparing values, behaviors, institutions, and organizations across nations. London: Sage Publications.

Hope, O.-K. (2003). Disclosure practices, enforcement of accounting standards, and analysts' forecast accuracy: An international study. Journal of Accounting Research, 41, 235-272.

House, R. J., Hanges, P. J., Javidan, M., Dorfman, P. W., \& Gupta, V. (2004). Culture, leadership, and organizations. The GLOBE study of 62 societies. London: Sage Publications.

House, R. J., Hanges, P. J., Ruiz-Quintanilla, S. A., Dorfman, P. W., Javidan, M., \& Dickson, M. W. (1999). Cultural influences on leadership and organizations: Project GLOBE. In W. H. Mobley, M. J. Gessner, \& V. Arnold (Eds.), Advances in global leadership (pp. 171-233). Greenwich, CT: JAI.

Ingleharts, R. (1977). The silent revolution changing values and political styles among western publics. Princeton, NJ: Pricenton University Press.

Ingleharts, R. (2001). Modernización y posmodernización: El cambio cultural, económico y político en 43 sociedades. Madrid: CIS.

Institute of Business Ethics. (2011, September). Business Ethics and Board Diversity. Business Ethics Briefing, 21:1.

Konrad, A. M., Kramer, V. W., \& Erkut, S. (2008). Critical mass: The impact of three or more women on corporate boards. Organizational Dynamics, 37(2), 145-164.

Konrad, A. M., \& Mangel, R. (2000). The impact of work-life programs on firm productivity. Strategic Management Journal, 21,1225 .
Konrad, A. M., Ritchie, J. E., \& Corrigal, E. (2000). Sex differences and similarities in job attribute preferences: A meta-analysis. Psychological Bulletin, 126, 593-641.

Kramer, V. W., Konrad, A. M., \& Erkut, S. (2006). Critical mass on corporate boards: Why three or more women enhance governance. Wellesley Centers for Women, Report No. WCW 11. Wellesley, MA: Wellesley Centers for Women.

Labelle, R., Francoeur, C., \& Makni Gargouri, R. (2010). Ethics, diversity management and financial reporting quality. Journal of Business Ethics, 93(2), 335-353.

Li, J., \& Harrison, J. R. (2008). National culture and the composition and leadership structure of boards of directors. Corporate Governance, 16(5), 375-385.

Lubatkin, M. H., Lane, P. J., Collin, S. O., \& Very, P. (2005). Origins of corporate governance in the USA, Sweden and France. Organization Studies, 26(6), 867-888.

Lubatkin, M. H., Lane, P. J., Collin, S. O., \& Very, P. (2007). An embeddedness framing of governance and opportunism: Towards a cross-nationally accommodating theory of agency. Journal of Organizational Behavior, 28, 43-58.

McCormick Hyland, M. A., \& Marcellino, P. A. (2002). Examining gender on corporate boards: A regional study. Corporate Governance, 2, 24-31.

McDonald, M. (2000). A start-up of her own. US News and World Report, 128(19), 34-42.

Meyer, J. W., \& Rowan, B. (1977). Institutionalized organizations; formal structures as myth and ceremony. American Journal of Sociology, 83, 364-385.

Moore, G., \& Shackman, G. (1996). Gender and authority: A crossnational study. Social Science Quarterly, 77, 274-288.

Nelson, T., \& Levesque, L. L. (2007). The status of women in corporate governance in high-growth, high-potential firms. Entrepreneurship Theory and Practice, 31(2), 209-232.

Nuss, S., \& Majka, L. (1983). The economic integration of women: A cross-national investigation. Work and Occupations: An International Sociological Journal, 10, 29-48.

Oakley, J. (2000). Gender-based barriers to senior management positions: Understanding the scarcity of female CEOs. Journal of Business Ethics, 27(4), 321-334.

Palvia, A., Vähämaa, E., \& Vähämaa, S. (2012). Do female CEOs and chairs constrain bank risk-taking? Evidence from the Financial Crisis. Working Paper in 25th Australasian Finance and Banking Conference 2012. SSRN: http://ssrn.com/abstract=2136978.

Paxton, P. (1997). Women in national legislatures: A cross-national analysis. Social Science Research, 26, 442-464.

Pedersen, T., \& Thomsen, S. (1997). European patterns of corporate ownership: A twelve-country study. Journal of International Business Studies, 28, 759-778.

Peng, M. W. (2004). Outside directors and firm performance during institutional transitions. Strategic Management Journal, 25, 453.

Ralston, D. A., Gustafson, D. J., Cheung, F. M., \& Terpstra, R. H. (1993). Differences in managerial values: A study of US, Hong Kong and PRC managers. Journal of International Business Studies, 24, 249-275.

Robbins, S. (2004). Comportamiento organizacional. Mexico City: Pearson Education de Mexico.

Salter, S. B., \& Niswander, F. (1995). Cultural influence on the development of accounting systems internationally: A test of Gray's (1988) theory. Journal of International Business Studies, 26, 379-397.

Sander, W., \& Boivie, S. (2004). Sorting things out: Valuation of new firms in uncertain markets. Strategic Management Journal, 25, 167.

Schuler, R. S., \& Rogovsky, N. (1998). Understanding compensation practice variation across firms: The impact of national culture. Journal of International Business Studies, 29, 159-177. 
Schwartz, S. H. (1986). Beyond the first generation of women directors: on the other side of the roadblock. Directors and Boards, 11(1), 39-41.

Schwartz, S. H. (1992). Universals in the content and structure of values: Theoretical advances and empirical tests in 20 countries. Advances in Experimental Social Psychology, 25, 1-65.

Scott, W. R. (1987). Organizations: Rational, natural and open systems. Englewood Cliffs, NJ: Prentice Hall.

Sealy, R., Doldor, E., \& Vinnicombe, S. (2009a). Increasing diversity on public and private sector boards. Part 1: How diverse are boards and why? Cranfield School of Management Report commissioned by the UK Government Equalities Office, October pp. 64.

Sealy, R., Doldor, E., \& Vinnicombe, S. (2009b). Increasing diversity on public and private sector boards. Part 2: What is being done to improve diversity on boards and how effective is this? Cranfield School of Management Report commissioned by the UK Government Equalities Office, November pp. 64.

Semenov, R. (2000). Cross-country differences in economic governance: Culture as a major explanatory factor. Center dissertation, Tilburg.

Smith, E. (2007). Gender influence on firm-level entrepreneurship through the power structure of boards. Women in Management Review, 22(3), 168-186.
Spain Equality Law. Ley Orgánica de Igualdad (2007). Ley Organica $3 / 2007$, de 22 de marzo, para la igualdad efectiva de mujeres y hombres. BOE no 71 de 23/3/2007.

Starbuck, W. H. (1976). Organizational structure. Annual Review of Sociology, 1, 1-20.

Strydom, M., \& Au Yong, H. H. (2012). The Token Woman. Working Paper in 25th Australasian Finance and Banking Conference 2012, SSRN: http://ssrn.com/abstract=2136737.

Stulz, R. M., \& Williamson, R. (2003). Culture, openness and finance. Journal of Financial Economics, 70(3), 313-349.

Terjesen, S., Sealy, R., \& Singh, V. (2009). Women directors on corporate boards: A review and research agenda. Corporate Governance: An International Review, 17(3), 320-337.

Terjesen, S., \& Singh, V. (2008). Female presence on corporate boards: A multi-country study of environmental context. Journal of Business Ethics, 83(1), 55-63.

Trompenaars, F. (1993). Riding the waves of culture: Understanding cultural diversity in business. London: Nicholas Brealey.

Very, P., Lubatkin, M., Calori, R., \& Veiga, J. (1997). Relative standing and the performance of recently acquired European Firms. Strategic Management Journal., 18(8), 593-614.

Zelechoski, D., \& Bilimoria, D. (2004). Characteristic of women and men corporate inside directors in the US. Corporate Governance. An International Review, 12(3), 337-342. 